\title{
Multianalytical Study for Establishing the Historical Contexts of the Church of the Holy Archangels from Cicau, Alba County, Romania, for its Promotion as a World Heritage Good
}

\author{
I. Assessing the preservation-restoration works from the $18^{\text {th }}$ century
}

\begin{abstract}
ION SANDU ${ }^{1,2}$, COSMIN TUDOR IURCOVSCHI ${ }^{3}$, IOAN GABRIEL SANDU2,4*, VIORICA VASILACHE ${ }^{*}$, IOAN CRISTINEL NEGRU³, MIHAI BREBU ${ }^{5}$, PETRONELA SPIRIDON URSU ${ }^{1}$, VASILE PELIN ${ }^{6}$

${ }^{1}$ Alexandru Ioan Cuza University of lasi, Institute of Interdisciplinary Research - Sciences Department, ARHEOINVEST Center, 11 Carol I Blvd., lasi, Romania

${ }^{2}$ Romanian Inventors Forum, 3 Sf Petru Movila Str, BI L11, Sc A, 3-3, 700089, lasi, Romania

${ }^{3}$ Alexandru loan Cuza University, Faculty of Geography and Geology, Doctoral School of Geosciences, 20A,Carol I Blvd, Corp B Etaj 1, 700506, Iasi, Romania

${ }^{4}$ Gheorghe Asachi Technical University of Ia'i, Faculty of Material Sciences and Engineering, 69 Dumitru Mangeron Str., 700050, lasi, Romania

${ }^{5}$ Petru Poni Institute of Macromolecular Chemistry, Polymer Physical Chemistry Dept., 41A Gr Ghica Voda Alley, 700487, Iasi, Romania

${ }^{6}$ Alexandru Ioan Cuza University, Faculty of Geography and Geology, Environmental Sciences Department, 20A, Carol I Blvd, Corp B Etaj 1, 700506, Iasi, Romania

The present paper is the firstinstalment of a series focused on establishing some archaeometric characteristics of the modern finishings (mortars, fresco and layers of whitewash) of the Church of the Holy Archangels from Cicãu, Alba County, Romania, in order to assess the shape, with the structural-functional integrity and architectural and artistic aspect of the monument for the last historical context, between 1710 and 1790 . This period is the most extensive and less known of the church's stages of transformation: $11^{\text {th }}-12^{\text {th }}$ century (unknown), $15^{\text {th }}$ century (known) and $18^{\text {th }}$ century (partially known), which was very tumultuous from the socio-economic and political point of view. Thus, in the following pages we present the resulting archaeometric characteristics of optical microscopy $(O M)$, scanning electron microscopes in combination with energy-dispersive X-Ray spectrometry (SEM-EDX) and thermal derivatography (TG/DTA/DTG) analyses of two pigments from the exonarthex fresco (made in 1781) and the later eight layers of whitewash applied over it, which allowed assessing the periods with marked changes in the architecture and polychrome finishings.
\end{abstract}

Keywords: Old fresco, intonaco, arriccio, overlapping whitewash, OM, SEM-EDX, thermal derivatography

In the life path of a historical monument or heritage artefact, from the execution stage to museification, there is a series of periods with major changes undergone by the heritage elements, in the form of the elements acquired since conception (the nature of the materials, artistic technique, manufacturing or building technology, author/ workshop, period/area of use, etc.), but also under the imprint of time (age/patina, interventions to preserverestore/falsify, deterioration and degradation effects that are stabilised or evolutive, etc.) and of the heritage functions (aesthetic-artistic; historical-documentary; technicalscientific; socio-economic and public utility; spiritual, with absolute priority/primary/unique). These are recognised as historical contexts, which under the influence particularly of natural (calamities or cataclysms) and anthropic risk factors (catastrophes or disasters, socio-economic or military crises, etc.), mark the evolution of a national or universal heritage good. According to the historical contexts, particularly the latter, and in correlation with the value of the heritage elements of functions, we can speak of the following paths [1-4]:

- normal, with preservation-restoration interventions demanded by the state of conservation and reintroduction into the museum circuit;

- abandonment, at the loss of the heritage functions and archaeological discovery (involving operations of preliminary consolidation, cleaning, restoration, and definite preservation), followed by introduction into the collection:

- lost, hidingand forgetting or theft, followed by discovery; - plagues (generalised epidemic or pandemic), the elements, natural or anthropic hazards.

The last two groups of paths, after discovery, all have the same stages of valorisation as in the path through abandonment.

With respect to the description of the historical contexts, of concern are the stages and objectives of each: creation or conception (design), manufacturing or execution, use or displaying, abandonment (with the context of discovery), scientific investigation (for carrying out the six expert reports: authentication, heritage assessment by establishing the market or catalogue value, determining the state of conservation, the compatibility of the new materials and technologies of preservation-restoration, monitoring the behaviour of the interventions for a set timespan, monitoring the state of conservation during exhibition or storage), preservation, restoration and reintroduction into the heritage circuit. For a context or in transition phases, we can speak of the shape and aspect of the object, the structural-functional integrity, the age patina, the presence of interventions subsequent to the execution, etc. $[1-3,5]$. 
In the case of old monuments, which have lasted and continue to have elements with distinguished historical and artistic significance, but for which there aren'tsufficient historiographic data, the archaeological and technicalscientific investigation, involving multianalytical methods, in co-assistance or corroboration of modern instrumental techniques, allows determining the chemical and physicalstructural nature of the component materials and their state of conservation, elucidating the mechanism of deterioration and degradation [8-14]. From these, the microscopic, spectral and thermogravimetric techniques allow identifying a number of archaeometric characteristics or chemometric characteristics with archaeometric function, very important in valorising through their integrated conservation, environmental and cultural [15-17]. Particular attention is given to certain hidden, unknown elements, to preservation-restoration interventions, with major structural-functional changes, or those unauthorised (vandalism) and to certain evolutive anthropic effects or of high risk (wars, revolts, fires, demolitions, etc.).

The National Cultural Heritage consists of numerous historical monuments and artefacts, found on UNESCO's Universal Heritage and Protection lists, but, as is it well known, Romania still has undiscovered treasures and lesser-known or valorised monuments. Among them, the Church of the Holy Archangels from Cicau, inscribed on the List of Historical Monuments from Alba County [18, 19], with the LMI Code (2015) AB-II-m-A-00203, one of the oldest Christian Orthodox stone churches of Transylvania, which witnessed a series of changes throughouttime, still preserves layers of painting from three periods: the $11^{\text {th }}-12^{\text {th }}$ centuries, the $15^{\text {th }}$ century and, respectively, the $18^{\text {th }}$ century. From the latter two periods, there still exist the fresco, finishings and whitewash layers, alongside structural elements, and historiographical data. With respect to the first period, in the village there still is the oral lore according to which the church is much older than the known historiographical data [20-22]. At the request of local officials wishing to include the church on the UNESCO World Heritage List, our team was solicited to carry out a complete expert authentication assessment, and to establish the archaeometric characteristics for determining the execution moment and the main changes occurring during the three historical contexts. After collecting the samples from the fresco, finishings and exposed stone (walls and foundation),

This paper constitutes the first instalment of a wider series meant to establish a number of archaeometric characteristics in order to assess the shape, with the structural-functional integrity and of the architectural and artistic aspect of the monument in the three historical contexts $-11^{\text {th }}-12^{\text {th }}$ centuries, $15^{\text {th }}$ century and, respectively, $18^{\text {th }}$ century -, the changes concerning the constructive and chromatic reintegrations that followed the last context (18 $8^{\text {th }}$ century), a period of socio-economic and political upheaval in Transylvania, which affected very much this area.

Thus, through optical microscopy (OM), scanning electron microscopes in combination with energydispersive X-Ray spectrometry (SEM-EDX) and thermal derivatography (TG/DTA/DTG), for two pigments of the fresco from the exonarthex (outer narthex; Rmn. pridvor) and the eight whitewash layers overlapping the fresco, a series of archaeometric characteristics were established, which allowed assessing the periods with changes in the architecture and polychrome finishings carried out in 17101790.

\section{Experimental part}

Historiographical analysis. Brief description of the monument

The Church of the Holy Archangels in Cicau, Miraslau commune (fig. 1) was, according to the known data [19], built in 1495, with significant transformations after 1710 . The interior painting, which has survived in the Altar and the Naos, is particularly valuable but in a relatively poor state of conservation (fig. 2). From the stratigraphic point of view (by means of coring), three layers of fresco are found, dating from the $18^{\text {th }}$ century, the $15^{\text {th }}$ century and, respectively, a much older one, from the $11^{\text {th }}-12^{\text {th }}$ century. Part of the $18^{\text {th }}$ century fresco from the esonarthex (inner narthex; Rmn. pronaos) is found under several overlapping layers of whitewash. These aspects became noticeable during the photofixation, collecting pictorial/masonry materials, and various calorimetry measurements through reflexion and reflectography (fig. 3).



Fig. 1. General view from the South of the Church of the Holy Archangels from Cicau, Alba County

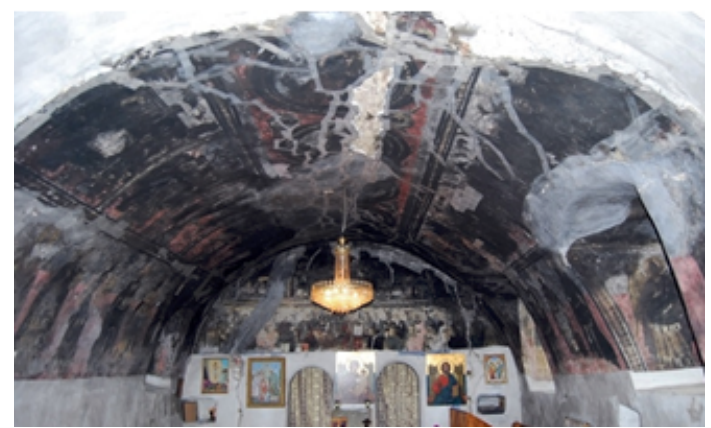

Fig. 2. The fresco from the nave (1495)

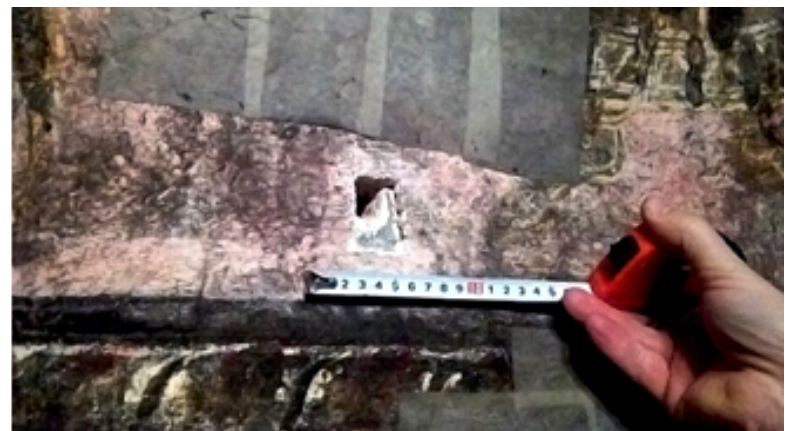

Fig. 3. Stratigraphic view of the two fresco through the coring

From the architectural point of view, the church is currently comprised of a roofed esonarthex, superimposed by the bell tower (fig. 1), the nave (Rmn. naos) and the altar, with a hemicylindrical vault and polygonal recessed apse, which are covered by an ellipsoid vault (fig. 2). Initially, according to the available historiographical and archaeological data, the church was composed of nave 
and the altar, divided by an altar screen made of a single large stone slab, possibly from a sandstone concretion with an adequate planimetry and thickness, brought from the stone quarry located a few meters away. The altar screen has only two entries (the royal door on the right, and the deacon's door on the left) carved into the rock (fig. 2). After 1700, the old nave was extended westwards, with the present-day esonarthex, and the western wall demolished, while the old stone frame of the initial entry was moved to the southern side of the new esonarthex, where a new exonarthex was built [19]. Currently, only the western wall and the external foundation from the South and East have been preserved (fig. 4).

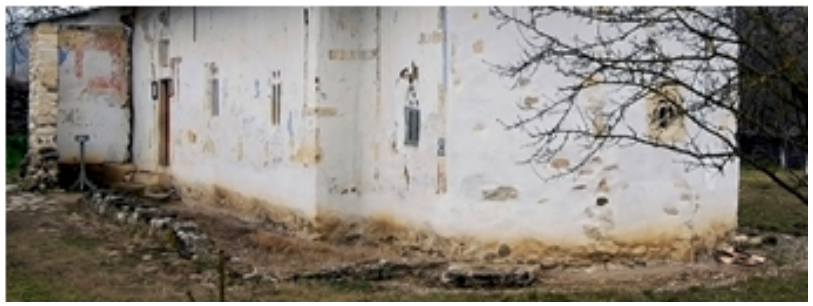

Fig. 4. The entry door and the remains of the exonarthex from $1775-1780$

The church has six windows, five of which found in the older part. The windows are lobe-shaped, of Gothic style, with stone frames embellished by carving and chiselling (fig. 5a). The window on the eastern side of the altar is round (Fig. 5b), with tracery, four-lobbed in shape, while the other four are mullioned (fig. 5c-e), with a semicircular closing at the top, and three round holes above [19].



Fig. 5. Details with the five windows from the old part of the church: a-c. from the nave and esonarthex (South); d. from the altar (East); e. from the nave (North)

The advanced state of deterioration and degradation of the building required restoration works to be carried out, which took place in 1995-1998. Before the restauration works commenced, a team lead by Gheorghe Petrov from the National History Museum of Transylvania in ClujNapoca carried out archaeological excavations and investigations, both inside and outside the church, which lead to the discovery of 99 tombs, with a diverse funerary inventory (medieval and modern coins, jewellery, clothing accessories, etc.). The oldest coin discovered in one of the tombs is a silver denarius, issued in 1479-1485, during the rule of Matthias Corvinus. The restoration works, finished in 1998, did not include the interior painting of the church. The first painting layer, visible in the nave near the altar, dates from the firsthalf of the $15^{\text {th }}$ century, while the second, from the esonarthex, from the $18^{\text {th }}$ century. The latter painting was made by painter loan (lacob) Boer from Teius, also known as lacov Zugravul (Jacob the Painter) [19], but, according to other sources, by his son Gheorghe [2022].

This worship building has typological resemblance to the churches of St. George from Lup'a (ca. 1421) and St. Paraskevi from Feleac (1488) [19], and the fresco is close to those from the churches of Dormition of the Mother of God and, respectively, Life-giving Spring from Râme [21].

\section{The state of conservation of the monument}

Presently, after the interventions at the foundations and the roof, followed by improving through restoration the western wall, originating from the stone frame of the entry on the southern side of the last esonarthex and of the foundations left on the southern and eastern sides, the church entered the tourist circuit (fig. 6).

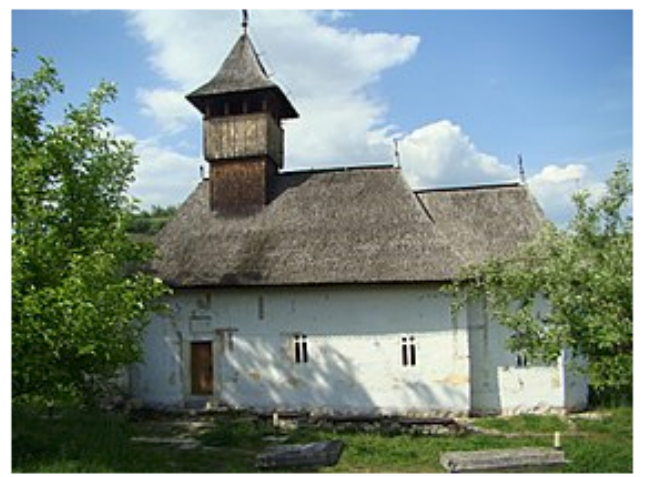

Fig. 6. Overall image from the South of the Church of the Holy Archangels from Cicau, before the 1995-1998 restoration works. Photo source: Tetcu Mircea Rares, 2009 [23]

This church is a notorious example of improper restoration interventions, for which the norms of the Code of Ethics of the Conservation Science for historical monuments, unanimously accepted worldwide [24]. The interventions affected the overall image of the monument, both at the inside and outside. They were due to the lack of financial resources and qualified and certified personnel; instead, the workers applied nonconforming adhesive tape over the dynamic crackles in order to stop the deterioration of the interior frescoes (fig. 7), rebuilt the western wall of the exonarthex using ornate stone from other part of the old nave, and failed to consolidate the fissure from the joint with the main segment of the church; then, they applied a layer of whitewash over the exterior fresco, and did not restore the exposed foundation (fig. 8).

Likewise incorrectly finished were the consolidation works for some of the masonry elements, the cleared area kept as markers, and others (fig. 9).

Exemplifying this situation, we can observe in figure 10 the advanced state of degradation of the southern and eastern facades. The images clearly show at least four rows of whitewash over the original painting. Also

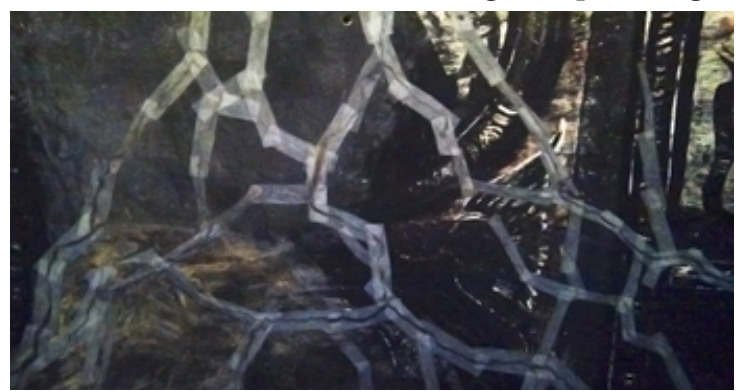

Fig. 7. Detail of the adhesive tape applied over the dynamic crackles in order to stop the deterioration of the interior frescoes 




Fig. 8. Improper preservationrestoration interventions

Fig. 9. Improper interventions for consolidating and preserving the reference marker areas

observable are the written graffiti (vandalism) through which people marked their presence in the church or their feelings for others by scratching or engraving heart shapes and other markings on the wall [25].

Details with inadequate interventions and signs of vandalism [25].

Another highly intriguing aspect is that the tourist indicator located $6 \mathrm{~km}$ from the church specifies that the monument is made of wood, not masonry. This reveals the carelessness of those who produced the indicator, as well as of those who favourably sanctioned its setting up. Furthermore, until 2009 it was still possible to read the presentation info on the panel erected in the church's courtyard, in three languages: Romanian, French and English. Much to the confusion of tourists, the French version claimed that the church was Reformed, as can be seen in Figure 11, without further clarification, such as the period and the reason. Even though this indicator has since disappeared, there still remains the question how were the panels approved in the first place?

The period between 1710 and 1780, for Alba County, was one of tremendous upheaval, culminating with the Revolt of Horea, Closca and Crisan (1784) and the oppression of the peasants of Cicau. The changes in the constructive and chromatic reintegrations, which followed the $15^{\text {th }}$-century context, can be explained by this socioeconomic and political turmoil in Transylvania, which affected very much this area. During this period, the church from Cicãu was converted from an Orthodox to a Reformed one, switching back in the $19^{\text {th }}$ century. In 1781, the second layer of fresco was made in the nave and esonarthex. This came several decades after a number of major structuralfunctional changes were carried out in the exonarthex in the esonarthex, by extending the church westwards and erecting an elongated exonarthex ( târna III) on the southern side, along the central nave, in order to increase the prayer space. The same year (1781) also witnessed the painting of the fresco in the exonarthex and the changing of the windows and doors, now mounted in sandstone frames. The fresco in the exonarthex was covered after 1790 by the first layer of whitewash, which repeated for seven times for each $20-50$ years.

\section{Collecting and processing the samples}

Initially, alongside an expert team from the Laboratory of Scientific Investigation from the Arheoinvest Interdisciplinary Research Platform of the Al. I. Cuza University of Ia'i, we performed the detailed photofixation of the representative areas of the two interior and, respectively, exterior frescoes, of a number of structuralfunctional elements of the monument, with evolutive deteriorations and degradations, by marking the preservation and restoration interventions, particularly those performed improperly, collecting samples from noninvasive micro-corings or from crackles and other dynamic structures in the painting and masonry materials, followed by calorimetric measurements by reflexion and reflectography on the polychrome surfaces.
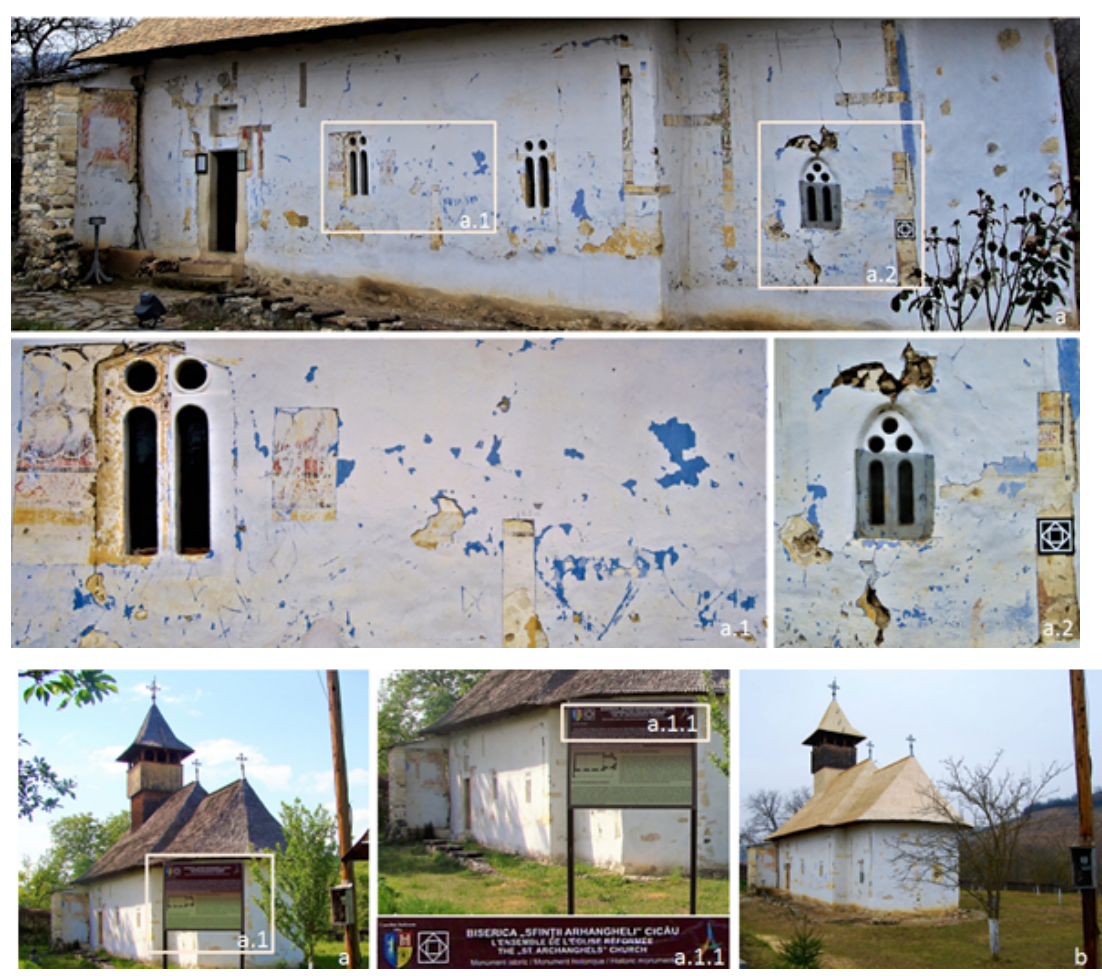

REV.CHIM. (Bucharest) $70 \diamond$ No. 7 \2019

http://www.revistadechimie.ro
Fig. 10. The Church of the Holy Archangels (1495) from Cicau:

a.1. and a.2. Details with inadequate interventions and signs of vandalism [25]

Fig. 11. The Church of the Holy Archangels (1495) from Cicau; a, a.1 and a.1.1. Details with the presence of the indicator $[25,26] ; b$. overall image without the indicator from during the period when the samples were collected 


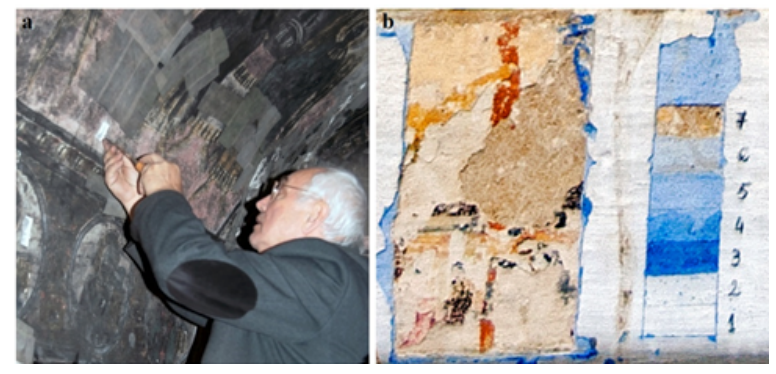

Fig. 12. Areas for collecting pictorial material samples: a. from the interior frescoes:b. from the overlapping whitewash layers covering the exterior fresco

Figure 12 presents the areas from where samples were collected of the pictorial material of the interior frescoes and of the overlapping whitewash layers over the exterior fresco.

The pictorial material samples were analysed by optical microscopy, electronic microscopy coupled with X-ray spectrometry, and thermal analysis through dynamic thermal derivatography (TG, DTA, DTG).

The optical microscopy (OM) analysis was made using a Carl Zeiss Axio Imager Alm microscope, which allows working in bright or dark environments, in visible or UV range, and fitted with a Axiocam camera.

The SEM-EDX analysis was performed using a Tescan (Czechia) VEGA II LSH scanning electron microscope, coupled to an EDX detector type Quantax QX2 by Bruker/ Roentec, Germany.

For the dynamic thermal analysis, the pictorial samples were analysed using a Linseis derivatograph.

\section{Results and discussions}

Figure 13 presents the OM microphotographic images at a $5 \times$ magnification of the two samples of colour (ochre and green) from the exterior fresco and of the eight whitewash samples from the layers covering the exterior fresco (L1-V8). We notice the degradation of these samples from processes of oxidative fouling and chromatic shift through acido-basic and redox processes.

Figure 14 presents the SEM microphotographs, and Table 1 the data of elemental analysis assessed from the EDX spectra of the two colour samples (ochre and green) from the exterior fresco and the eight whitewash samples covering it (in these experiments, the samples L4, L5 and L6 were dropped because they had very similar characterictis with samples L1, L2 and L3; henceforth, sample $L 7$ becomes $L 4$, and sample $L 8$ becomes $L 5$ ).

The data in table 1 show that the process of carbonation represented by the concentration in carbon, calcium and oxygen is an edifying archaeometric characteristic, with the whitew ash layers being applied in the L1-L5 order. With respect to the moments when the whitewash layers were applied, starting from 1781, the year the exterior fresco was painted, by involving the chemometric characteristics $\Delta \mathrm{C} \%=\mathrm{C}-\mathrm{C}_{(,,}$, we can approximate the following dates: the first whitewash layer was applied ca. 6-8 years $(\Delta \mathrm{C} \%$ $=0), \sim 1792$; the second layer after $18-20$ years $(\Delta C \%=$ $1.181), \sim 1812$; the third after another ca. $48-50$ years $(\Delta \mathrm{C} \%$ $=0.397), \sim 1862$; the fourth after $\mathrm{Ca}$. $50-55$ years $(\Delta \mathrm{C} \%=$ $0.042), \sim 1912$; and the fifth after another ca. 60-65 years $(\Delta C \%=0.038), \sim 1977$. This is a good fitting for a period of 220 years.

The samples for derivatography were an ochre and, respectively, green pigment, as well as the five representative whitewash samples. They were recorded at a speed of $12^{\circ} \mathrm{C} / \mathrm{min}$.

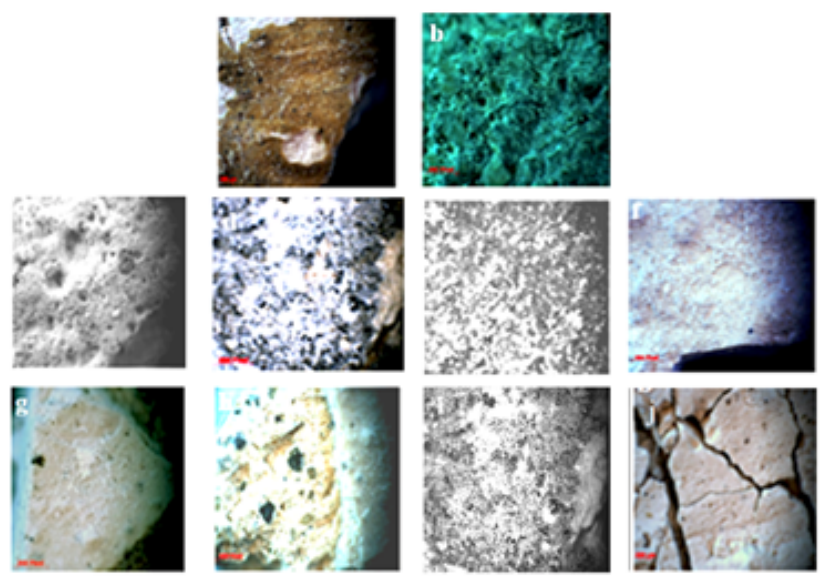

Fig. 13. OM microphotographic images $(5 x)$ of the colour samples from the exterior fresco and the eight samples from the whitewash layers covering the exterior fresco: a. ochre; b. green; $c . L 1 ; d . L 2$; e. L3; f. L4; g. L5; h. L6; i. L7; j.L8
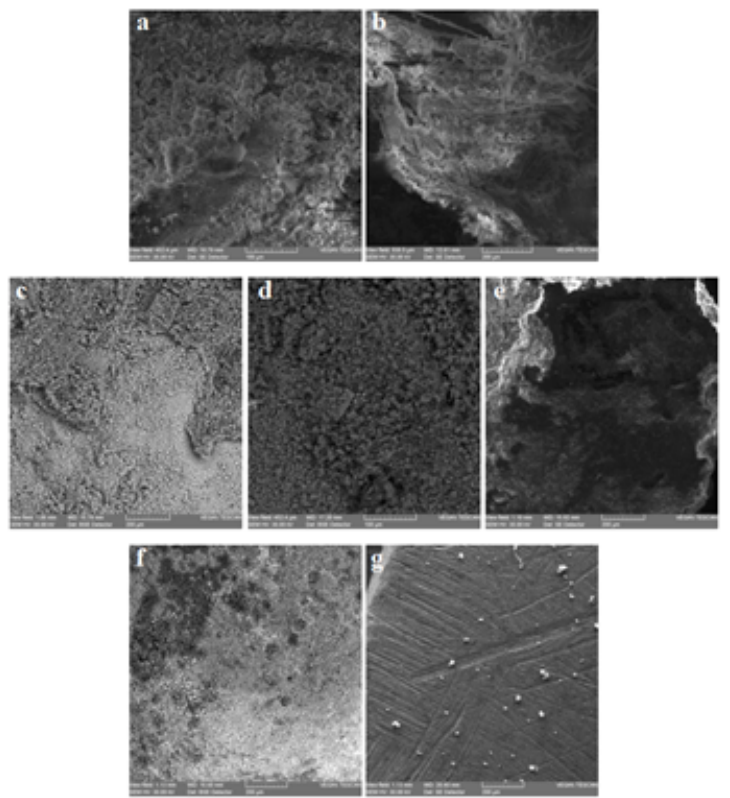

Fig. 14. SEM microphotographs of the two colour samples (ochre and green) from the exterior fresco and a selection of five representative samples from the eight collected from the whitewash layers covering the exterior fresco: $a$. ochre; b. green; C. L1; d. L2; e. L3; f. L4; g. L5

On the basis of the derivatograms of the two groups of samples-two pigments from the exterior fresco (ochre and green), which are representative for this period, and, respectively, five samples of whitewash from the layers covering the exterior fresco-,using a processing software (Proteus), we ascertained the evolution of the two important characteristics (TG-\% and DTG-\%/min), on the basis of which we assessed the archaeometric characteristics for thermal behaviour in dynamic conditions at a speed of $12^{\circ} \mathrm{C} / \mathrm{min}$, presented in figure 15 .

The two pigments, representative for the exterior fresco from the chronological timespan under scrutiny, displayed similar thermal behaviour. A main process can be observed between $\sim 690-700^{\circ} \mathrm{C}$ and $\sim 885^{\circ} \mathrm{C}$, with a maximum speed at $\sim 845^{\circ} \mathrm{C}$ and a mass loss of $\sim 35 \%$. Between $\sim 310^{\circ} \mathrm{C}$ and $\sim 480^{\circ} \mathrm{C}$, another process with mass loss occurs, which presents two stages for the ochre layer (with a maximum speed at $\sim 350^{\circ} \mathrm{C}$ and $\sim 440^{\circ} \mathrm{C}$ ), while for the green layer it appears only in the stage from $\sim 395-480^{\circ} \mathrm{C}$. The green layer is more thermally stable at heating under $\sim 500^{\circ} \mathrm{C}$ ( $1 \%$ less mass loss than the ochre layer), but becomes slightly unstable at greater temperatures, with an $\sim 1 \%$ 
Table 1

ELEMENTAL COMPOSITION (\%W) FOR THE TWO PIGMENTS FROM THE EXTERIOR FRESCO AND THE FIVE REPRESENTATIVE WHITEWASH SAMPLES (L1-L5)

\begin{tabular}{|c|c|c|c|c|c|c|c|c|c|c|c|c|c|c|}
\hline \multirow{2}{*}{ sample } & & \multicolumn{13}{|c|}{ Elemental composition in gravimetric percentages } \\
\hline & $\mathrm{Si}$ & $\mathrm{Al}$ & $\mathrm{Fe}$ & $\mathrm{Pb}$ & $\mathrm{Ca}$ & $\mathrm{Mg}$ & $\mathrm{Cl}$ & $\mathrm{Na}$ & $\mathrm{K}$ & $\mathrm{P}$ & S & $\mathrm{C}$ & $\mathrm{O}$ & $\mathrm{Cu}$ \\
\hline Green & - & 64.748 & - & - & - & - & 0.800 & - & - & - & - & 9.742 & 19.855 & 4.855 \\
\hline Ochre & 1.649 & 0.995 & - & 8.925 & 43.276 & 1.069 & 0.784 & - & - & 0.582 & 0.891 & - & 41.829 & - \\
\hline $\mathrm{Ll}$ & 1.116 & 0.766 & 1.109 & - & 41.941 & 0.859 & - & 0.854 & - & - & - & 12.855 & 40.500 & - \\
\hline L2 & 2.606 & 1.186 & 1.153 & - & 40.271 & 1.037 & - & - & 3.530 & - & - & 12.071 & 38.146 & - \\
\hline L3 & 2.561 & 0.811 & 0.837 & - & 27.860 & 0.945 & 0.643 & 0.892 & 6.200 & - & - & 11.716 & 47.535 & - \\
\hline L4 & 1.134 & 0.477 & - & - & 30.330 & 1.741 & - & 0.876 & - & - & - & 11.712 & 53.730 & - \\
\hline $\mathrm{L} 5$ & 1.528 & 0.779 & - & - & 30.236 & 0.871 & - & 0.436 & 0.429 & 3.276 & - & 11.674 & 50.771 & - \\
\hline
\end{tabular}
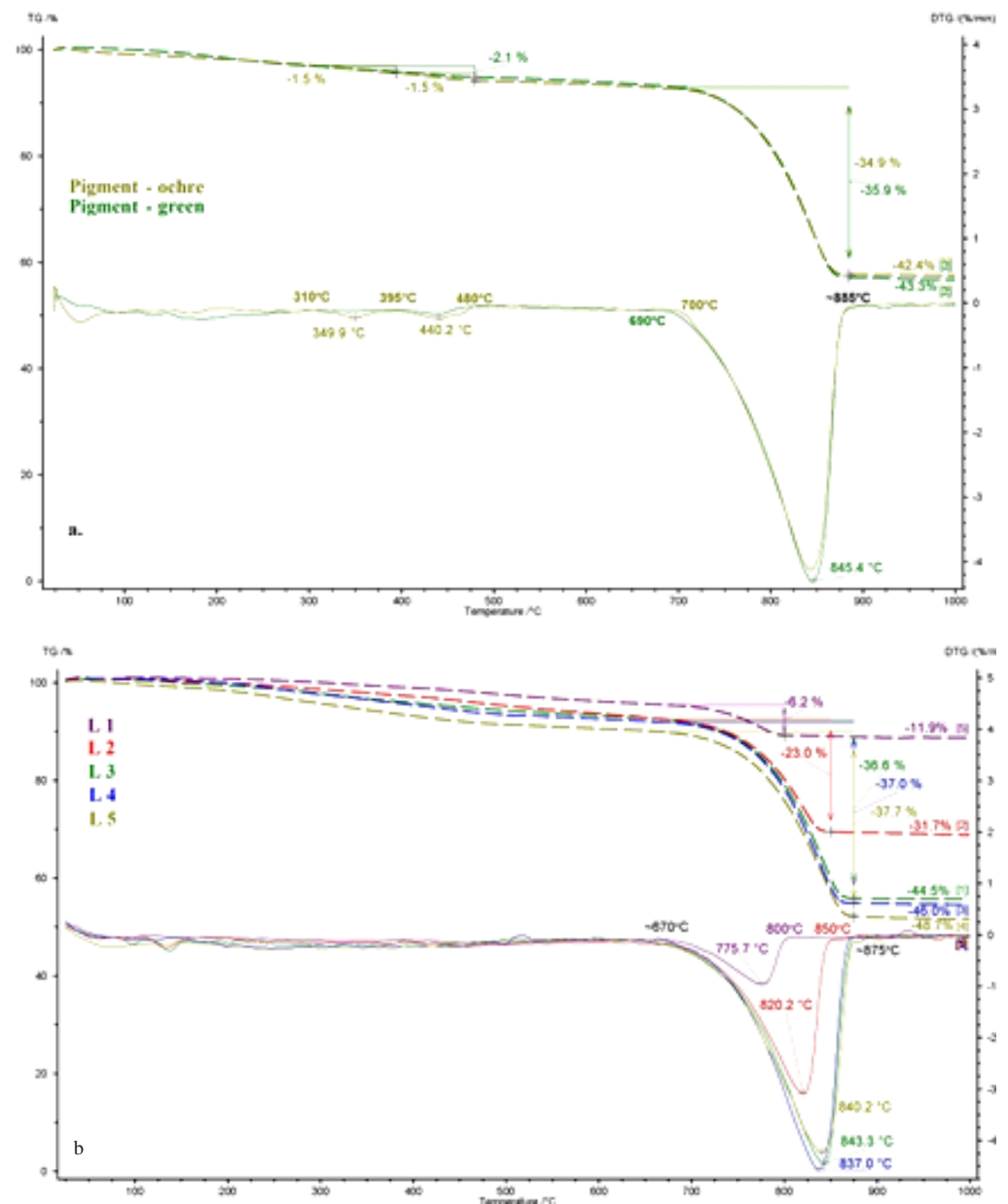

Fig. 15. Evolution of the two important characteristics (TG-\% and DTG-\%/min) for the pigment (a) and whitewash (b) samples

greater loss of mass in the main decomposition process, and commencing $\sim 10^{\circ} \mathrm{C}$ earlier compared with ochre layer. The final mass loss at $1000^{\circ} \mathrm{C}$ is $\sim 43 \%, \sim 1 \%$ more for the green layer. These behaviours, very close for the two pigments originating from coloured earth, demonstrates that they have the same age since execution.

Conversely, the five whitewash samples from the structures overlapping the exterior fresco, heated to $\sim 500$ $600^{\circ} \mathrm{C}$ present a gradual and continuous loss of mass of $\sim 4-10 \%$, without displaying clear DTG peaks. Temperatures over $\sim 670^{\circ} \mathrm{C}$ trigger a more rapid process of mass loss, which ends at $\sim 800-875^{\circ} \mathrm{C}$. Even though all samples start to lose mass faster at approximately the same temperature $\left(\sim 670^{\circ} \mathrm{C}\right)$, the process unfolds differently for each of the whitewash types analysed. Samples $L 5$ and $L 4$ have the temperature of the maximum speed of the process $\left(\sim 776^{\circ} \mathrm{C}\right.$ and, respectively, $\left.\sim 820^{\circ} \mathrm{C}\right)$ and the temperature of the end of the process $\left(\sim 800^{\circ} \mathrm{C}\right.$ and, respectively, $\sim 850^{\circ} \mathrm{C}$ ) significantly lower than the other samples $\left(\left(\mathrm{T}_{\text {max }} \sim 840^{\circ} \mathrm{C}, \mathrm{T}_{\text {fin }} \sim 875^{\circ} \mathrm{C}\right)\right.$. The thermal stability of the samples decreases in the order $L 1>L 2>L 3>L 4$
$>L 5$, with the degradation initiated at $\sim 670^{\circ} \mathrm{C}$ generating a process that unfolds in a wider temperature range and with a loss of mass greater as the thermal stability decreases. The small deviations in the evolution of these samples can be explained by the nature, calcination technology and provenance of the limestone used for producing the whitewash.

The archaeometric characteristics (the threshold for mass losses and the temperature domain specific to these losses) of the two pigment samples from figure 10a are almost identical (differences of ca. 1\%), which demonstrates that the execution took place simultaneously.

Conversely, for the whitewash samples, these characteristics present three strongly differentiated thresholds, which correspond to the periods the respective whitewash layers were applied, very differentiated in time: for sample L5 (the outer layer) of ca. 40 years ago, then sample L4 of 105 years ago, while samples L3, L2 and L1 were applied in a period between 155 and 225 years ago. 


\section{Conclusions}

The Church of the Holy Archangels from Cicau, Alba County, Romania, is a historical monument the origins of which are lost in time, and the historiographical data lists only two more important periods: the execution of 1495, when the interior frescoes were made, and the transformations of the early $18^{\text {th }}$ century, with the exterior frescoes and successive whitewashings.

On account of the manner and lack of attention given to the interventions, the monument is a bad example of preservation-restauration works, with great damage being brought both to the image of the church, as well as to the manner of approach in safeguarding for valorising the national cultural heritage.

The method of procedure, in preserving the frescoes by halting the evolution of the dynamic crackles and of the evolutive degradations through fouling, then in the solutions selected for a number of finishings and marker elements from the masonry structures, will all register rather as acts of vandalism, and not even of carelessness.

The presence of a very interesting altar-screen (from a single massive concretion slab), of multiple aggressive interventions or left unfinished, and of much older polychrome layers, demands that the monument be subjected to new scientific investigations, particularly with respect to the authenticity of the artistic and cultelements, and the execution technique.

By involving three modern analysis techniques, namely optical microscopy (OM), scanning electron microscopes in combination with energy-dispersive X-Ray spectrometry (SEM-EDX) and differential thermal derivatography (TG/ DTA/DTG), we confirmed the year 1781 and the moments of whitewashing (for two reasons: covering the exterior frescoes during the Reformation, and for periodical sanitisation, after certain periods of decay in conservation. If through optical and electronic microscopy we ascertained the state of conservation of the painting and finishing materials under scrutiny, from the elemental analysis data and, respectively, from the evolution of the two important characteristics (TG-\% and DTG-\%/min) we identified a series of archaeometric (carbonation rate) and chemometric (difference in the elemental concentration in $\mathrm{C} \% \mathrm{w}$, assessed through the formula $\left.\Delta \mathrm{C} \%=\mathrm{C}_{(i+1)}-\mathrm{C}_{(i \mathrm{i})}\right)$, on the basis of which we determined the moments when the whitewash layers were applied. Thus, starting from 1781, the year the external fresco was made, by involving the two groups of chemometric and archaeometric characteristics, the following approximations were made: the first whitewash was applied in $\sim 1792$, the second in $\sim 1812$, the third in $\sim 1862$, the third in $\sim 1862$, the fourth in $\sim 1912$, and the fifth in $\sim 1977$, being a good fitting for a period of 220 years.

\section{References}

1. SANDU, I., BRANZILA, M., SANDU, I.G., Scientific Conservation of the Stone Monuments, Al.I.Cuza University Publishing House, Iasi, 2009.

2. SANDU, I., Degradation and Deterioration of the Cultural Heritage, Vol. I and II, Al.I.Cuza University Publishing House, Iasi, 2008.

3. SANDU, I.G., SANDU, I., DIMA, A., Modern Aspects Concerning the Conservation of Cultural Heritage, vol.III. Autentication and Restauration of the Inorganic Material Artefacts, Ed. Performantica, lai, 2006.

4. SANDU, I.C.A., BRACCI, S., SANDU, I., Instrumental analyses used in the authentification of old paintings - I. Comparison between two icons of XIXth century, Rev.Chim. (Bucharest), 57, no. 8, 2006, p. 796. 5. CRISTACHE, R.A., SANDU, I.C.A., SIMIONESCU, A.E., VASILACHE, V., BUDU, A.M., SANDU, I., Multi-analytical Study of the Paint Layers Used in Authentication of Icon from XIXth Century, Rev.Chim. (Bucharest), 66, no. 7, 2015, p. 1034.
6. SANDU, I.C.A., SANDU, I., LUCA, C., Modern Aspects Concerning the Conservation of Cultural Heritage, vol.II. Autentication and Determination of the Old Paintings Conservation State, Ed. Performantica, lai, 2005.

7. SANDU, I., SANDU, I.C.A., van SAANEN, A., Scientific Expertize of the Art Works, vol I, .Al.I.Cuza University Publishing House lasi, 1998. 8. HAN, K., LEE, S., LEE, H., Study of the Painting Methods of Mural Paintings in Ancient Tombs of Goguryeo Using Scanning Electron Microscope, Microscopy and Microanalysis, 19, 2013, pp. 157-161, Supplement: 5, DOI: 10.1017/S1431927613012555

9. KRIZNAR, A., HOFLER, J., RUIZ-CONDE, A., SANCHEZ-SOTO, PJ., Archaeometric characterization of pigments and mortars from Gothic wall paintings (13-15th Centuries), Boletin de la Sociedad Espanola de Ceramica y Vidrio, 46(2), 2007, pp. 76-85, DOI: 10.3989/ cyv.2007.v46.i2.253.

10. HELVACI, Y.Z., DIAS, L., MANHITA, A., MARTINS, S., CARDOSO, A., CANDEIAS, A., GIL, M., Tracking old and new colours: Material study of 16th century mural paintings from Evora Cathedral (Southern Portugal), Color Research and Application, 41(SI3), 2016 pp.276-282, DOI: $10.1002 / \mathrm{col} .22040$

11. SAVIUC-PAVAL, A.M., SANDU, I., POPA, I.M., SANDU, I.C.A., VASILACHE, V., SANDU, I.G., Obtaining and Characterization of Ceramic Pigments for Polychrome Artistic Elements II. Microscopic and colorimetric analysis, Rev.Chim. (Bucharest), 63, no. 2, 2012, p. 170. 12. SAVIUC-PAVAL, A.M., SANDU, A.V., POPA, I.M., SANDU, I.C.A., BERTEA, A.P., SANDU, I., Colorimetric and microscopic study of the thermal behavior of new ceramic pigments, Microscopy Research and Technique, 76, no. 6, 2013, p. 564. DOI: 10.1002/jemt.22201.

13. SAVIUC-PAVAL, A.M., SANDU, I., POPA, I.M., SANDU, A.V., BREBU, M., SANDU, I.G., Obtaining and Characterization of New Ceramic Pigments for Polychrome Artistic Elements III. Thermogravimetric analysis, Rev.Chim. (Bucharest), 63, no. 3, 2012, p. 275.

14. PRUTEANU, S., VASILACHE, V., SANDU, I.C.A., BUDU, A.M., SANDU, I., Assessment of Cleaning Effectiveness for New Ecological Systems on Ancient Tempera Icon by Complementary Microscopy Techniques, Microscopy Research and Technique, 77, no. 12, 2014, p. 1060. DOI: 10.1002/jemt.22437.

15.TOMASSETTI, M., MARINI, F., CAMPANELLA, L., POSITANO, M., MARINUCCI, F., Suitable classification of mortars from ancient Roman and Renaissance frescoes using thermal analysis and chemometrics, Chemistry Central J ournal, 9, 2015, Article Number: 23, DOI: 10.1186/ s13065-015-0098-z

16.GATTA, T., CAMPANELLA, L., COLUZZA, C., MAMBRO, V., POSTORINO, P., TOMASSETTI, M., VISCO, G., Characterization of black pigment used in $30 \mathrm{BC}$ fresco wall paint using instrumental methods and chemometry, Chemistry Central Journal, 6(S2), 2012, Article Number: S2, DOI: 10.1186/1752-153X-6-S2-S2.

17. UNKOVIC, N., GRBIC, ML., SUBAKOV-SIMIC, G., STUPAR, M., VUKOJEVIC, J., JELIKIC, A., STANOJ EVIC, D., Biodeteriogenic and toxigenic agents on 17th century mural paintings and facade of the old church of the Holy Ascension (Veliki Krcimir, Serbia), Indoor and Built Environment, 25(5), 2016, pp. 826-837, DOI: 10.1177/ 1420326X15587178.

18. *** https://patrimoniu.gov.ro/images//mi-2015/LMI-AB.pdf

19. ***http://cimec.ro/Monumente/LacaseCult/RO/Documente/ BazaDate.htm

20. DUMITRAN, A., CUCUI, E.D., POP, S.F., MIHU, E., lacov Zugravul, Ed. Altip, Alba Iulia, 2010, pp. 68-70.

21. PORUMB, M., $O$ veche ctitorie romaneasca - biserica din Cicau (jud. Alba), Acta Musei Napocensis, 13, 1976, p. 285-291.

22. DUMITRAN, A., Repertoriul pictorilor identificati în judeul Alba pânã la mijlocul sec XIX, Patrimonivm Apvlense, 12, 2012, pp. 48-105. 23.*** ro.wikipedia.org/wiki/Fisier:Romania_Alba_Cicau_church_16. jpg

24. SANDU, I.C.A., SANDU, I., POPOIU, P., van SAANEN, A., Methodological Aspects Concerning Scientific Conservation of the Cultural Heritage, Ed. Corson, lasi, 2001.

25. SPIRIDON, P., Contribuii privind conservarea stiintificã integratã a patrimoniului cultural, PhD Thesis, Alexandru Ioan Cuza University of lasi, 2017.

26.*** ro.wikipedia.org/wiki/Fi'ier:Romania_Alba_Cicau_church_ 21.jpg

Manuscript received: 15.12 .2018 